\title{
WATER ENVIRONMENTAL REGULATION IN COLOMBIA
}

\author{
REGULACIÓN AMBIENTAL DEL AGUA EN COLOMBIA
}

David Tobón-Orozco ${ }^{1}$

Carlos Andrés Vasco Correa ${ }^{2}$

\begin{abstract}
Water resources are vital to life and economic development, but in Colombia they are under threat by negative externalities from diverse economic sectors. Water resource protection depends fundamentally on the quality and effectiveness of environmental regulation and Colombia seems to be an international reference point on environmental institutionalization given its completeness and comprehensiveness. However, Colombian water resources have declined in quality and availability over the last years. This reality motivated the development of an exhaustive analysis of Colombian water environmental regulation with an economic perspective. This article includes a review of the characteristics of these regulations concluding that the deterioration of water quality is not only the result of increasing population and economic development, but also of regulatory shortcomings due to institutional weakness, lack of enforcement, and the influence of interest groups.
\end{abstract}

\section{Key Words}

Environmental regulation, water, command and control, economic incentives, enforcement.

\section{Resumen}

Los recursos hídricos son vitales para la vida y el desarrollo económico, pero en Colombia están amenazados por externalidades negativas de diversos sectores económicos. La protección de los recursos hídricos depende fundamentalmente de la calidad y efectividad de la regulación ambiental y Colombia parece ser un punto de referencia internacional en institucionalización ambiental, dada su exhaustividad e integralidad. Sin embargo, los recursos hídricos colombianos han disminuido en calidad y disponibilidad en los últimos años. Esta realidad motivó el desarrollo de un análisis exhaustivo de la regulación ambiental hídrica colombiana con perspectiva económica. Este artículo incluye una revisión de las características de estas regulaciones, concluyendo que el deterioro de la calidad del agua no es solo el resultado del aumento de la población y el desarrollo económico, sino también de las deficiencias regulatorias debido a la debilidad institucional, la falta de cumplimiento y la influencia de grupos de interés.

\section{Palabras clave}

Regulación ambiental, agua, comando y control, incentivos económicos, aplicación.

\footnotetext{
${ }^{1}$ Universidad de Antioquia (Colombia). Correo electrónico: david.tobon@udea.edu.co

${ }^{2}$ Universidad de Antioquia (Colombia).Correo electrónico: carlos.vasco@udea.edu.co
} 


\section{Introduction}

According to New Institutional Economics (NIE), institutions decide the functioning of a society, whether by formal or informal rules, and its structures for compliance (North, 2008). Both requirements must be fulfilled since a formal rule that is not carried out is simply a dead letter (Ostrom, 2009). Environmental policy is part of an institutionalization aimed at regulating the behavior of actors in a market when their actions cause negative externalities for others, and the market does not respond to it. In Colombia, this institutionalization has been envisioned in a decentralized, participative and autonomous way, which would have certain merits: the affected parties have incentives to check its functioning and have greater information on how resources can be better used; the regulations are clearer, more participative and effective, and are not in conflict with other levels of government (Ostrom, 2009). However, decision-making must be transparent and democratic, and there must be clarity on the social cost of the agents' economic activities (their externalities) and, therefore, these agents must face exemplary sanctions.

Colombia has a complete environmental institutionalization, abundant natural resources, water resources, and an increasingly vibrant market economy that is approaching the level of a medium-income country. However, among rankings such as the Environmental Protection Index (EPI), Colombia was number 85 among 178 countries showing an alarming trend in the deterioration of its ecosystems and human health (Yale University, 2015), as well as in the extinction risk from climate change (Urban, 2015). It is therefore important to research the quality of these regulations, which can be characterized as a hybrid of Command-and-Control policies (CAC) and environmental taxes.

Another characteristic of the country's institutions is the asymmetry among them. There are better institutional allocations in the center and precarious allocations in the peripheries, as well as factors which are counterproductive to their proper functioning, such as a complex geography, territories controlled by illegal armed groups, political cronyism, and a socioeconomic context rife with income inequality (Rodríguez, 2012).

The aim of this article is to show the advances made in environmental regulation in an emerging country such as Colombia, in which apparently there is a great regulatory development, and which is a model of institutional involvement for other nations in the application of a hybrid between command-and-control standards and economic instruments. However, according to the authors' criteria, this complexity does not guarantee shielding the protection of water resources since it is difficult to enforce both for the regulator and the regulated.

Regarding the methods for regulating environmental externalities, it was believed that economic instruments (Pigouvian taxes, pollution permits, payment for environmental services) were more proper than CAC (technical and quantity standards) to adopt the social costs of pollution, encourage to reduce this pollution at efficiency levels and adopt cleaner technologies. These economic instruments provide flexibility to find the best solutions for each agent's restrictions, finding a lower tax payment or new market opportunities. However, these results are subject to the assumption of a "first best world" in which there are no additional failures such as: uncertainty and unequal distribution of information, limited wisdom, capital restrictions, undesirable behavior by the regulator (shortsightedness, lack of commitment and enforcement difficulties, being subject to capture or corruption), heterogeneity and market power of regulated agents, research and innovation activities with public-good characteristics, and different types of reduction technologies. For example, Bergek et al. (2014) show that CAC are preferred for their political acceptability or when there is uncertainty about the measurement of environmental costs; hybrid instruments are recommended as an immediate solution.

Prior to this paper, several studies have explored Colombian water legislation (Blackman, 2009; Kathuria, 2006; OECD, 2014; The World Bank, 1999) and argued that the effectiveness of environmental regulation is partially successful in only some watersheds due to problems such as: limited implementation, widespread refusal by municipal sewerage authorities, and a confused relationship between discharge fees and emission standards (Blackman, 2009); the need to make sectoral ministries accountable for the environmental impacts of their policies and strengthen the system of environmental management involving different levels of government and the environmental information system (OECD, 2014).The combination of environmental policy instruments including license fees, standards, charges, and subsidies reinforced by active enforcement led to an overall improvement in environment compliance (Kathuria, 2006).

This article provides an exhaustive review of Colombian environmental water regulation's main characteristics and a conceptual answer to the question of whether a broad combination of instruments helps or impairs the quality of 
regulations. It is based on the economics of regulation and environmental economy, as well as certain recent evaluations, highlighting institutional weakness, enforcement difficulties, and the generalized influence of interest groups.

\section{The complex regulatory institutionalism}

In Colombia, laws are defined by Congress, are the general frameworks that define environmental policies and are subject to compliance as per the 1991 Political Constitution. The Presidency of the Republic has the power to issue decrees as long as they are within the guidelines of the law. Ministries, which define sectoral policies, are part of the executive branch together with the Presidency and other government units at the regional (department) and local levels (municipalities, districts, and metropolitan areas). The Ministry of Environment and Sustainable Development (MADS for its acronyms in Spanish) oversees environmental regulation and is responsible for overseeing the management of the environment and renewable natural resources. The 33 regional autonomous corporations (CARs) are responsible for enforcing regulations, conducting surveillance and control activities, imposing fines and making investments to expand or maintain the supply of natural resources for the provision of ecosystem and water services to feed the aqueducts. Regional and local governments should support the functions of CARs (Tobón \& Vasco, 2019). This organizational model, which differentiates those who design the regulation from the regulatory compliance officials, is motivated by the idea of reducing the capture and control of institutions by increasing the number of agencies that fulfill the regulatory task, specializing in each activity, and generating checks and balance sheets between them, even if the cost of regulatory work increases (Kugler \& Rosenthal, 2000).

The judiciary also supports environmental policy through the Public Prosecutor's Office, together with the executive (Presidency, ministries and regional government units) and legislative powers (Congress). Fiscal accountability also includes valuation of environmental management and environmental costs and advancing processes of fiscal responsibility for damages to natural resources.

In Colombia more agencies were created from the 1991 Constitution to support the three traditional branches of public power, called autonomous bodies, complementing the work of CAR. The Comptroller general, in the exercise of his work, ensures the fiscal and managerial accountability of the public agencies and of agents or entities that manage public resources, and the Attorney general and the Office of the Ombudsman should watch and support compliance with environmental regulation.

The Ministry of Environment was merged with the ministries of Housing and Territorial Development in 2002 for "reasons of fiscal austerity and administrative efficiency" (Law 790 of 2002 of the Congress), reducing its management capabilities by entailing a reduction of resources and personnel to fulfill its environmental work, which is increasingly extensive and complex. In 2011 the functions of Environment and Housing were again separated under the name of MADS (Law 1444 of 2011 of the Congress). The MADS's management of environmental licenses, permits and formalities was then split to create the Environmental Licensing Agency (ANLA), as an autonomous and independent body (Presidential Decree 3573 of 2011). ANLA has become one of the most controversial institutions because it launched the licensing process through "express licenses" and by generating the social belief that obtaining environmental licenses became a simple requirement rather than a duty, and because of the extension of its functions, as well as the control and monitoring of firms' compliance with the management plans (Tobón \& Vasco, 2019).

Other public bodies enter the scene of Colombian environmental regulation of water resources, considering that the political decentralization established since the 1991 constitution also led to a decentralization in environmental management, and that regulation begins with the establishment of information systems on the territory, its environmental, economic, and social resources, development plans, land management and water uses. The above as a prelude to the application of technical regulations on the quantity, quality, and price of water, which are grouped into CAC policies and economic instruments. This is what is called the National Environmental System, to which the following entities are added: The National Planning Department (DNP), corporations and research institutes on environmental issues (IDEAM, Humboldt Institute, SINCHI, Invemar and IIAP), Colombian National Natural Parks, autonomous bodies and environmental and ecological police, citizen environmental authorities and non-state actors such as NGOs, environmental movements, and ethnic-territorial organizations.

The organization of special environmental areas involves the Ministry of Justice and the Constitutional Court, addressing 
conflicts between the interests of various ministries, by setting up prohibitions or limits on mining activity. In addition, environmental crimes were brought into such category in the reform of the Penal Code (Law 1453 of 2011). Some of the exceptional areas are managed by Colombia's National Natural Parks while others are managed by regional governments.

Transfers from the electricity sector to regional local governments are some of the most significant sources of income, and they are a compensation for the opportunity benefits of water uses by hydroelectric plants. These transfers were created in environmental law (Law 99 of 1993), but their interpretation and calculation are moderated by the Energy and Gas Regulatory Commission (CREG). In the precision of CAC policies on the use and quality of water discharged by agribusiness, there is a complementary or substitute role to the work of MADS and CARs of the ministries of health and agriculture, and the body in charge of technical standards and quality certifications - Colombian Institute of Technical Regulations and Certification (ICONTEC) - .

While subsidy types are defined by Congress and range from better technologies and production processes to the promotion of private initiatives such as payments for environmental services to those who protect environmental and aquifer reservoirs, companies must be registered in the National Science and Technology System and subsidy caps are set up by the Ministry of Finance.

Since the 1991 constitutional reform in Colombia, both the regulations and the institutions in charge of the regulation of the water resource have been increasingly expanded. The financing of these organizations is limited by the growth of the nation's overall budget; as the resources of these organizations do not depend on regulatory management, they must be shared among all of them, and their tasks and technical complexity increase. As will be explained later, the taxes collected by the application of all economic instruments are ridiculously small. Decisions on the strictness of the national water environmental policy should strike a ministerial balance, as is the case with the ongoing feud between the Ministries of Mines and Energy and the Ministry of Environment on issues such as mining exclusion zones, the Ministry of Finance's support for obtaining fiscal resources in an emerging country that focuses on accelerated growth with pressing needs such as poverty reduction, and the medium-term fiscal rule to be met (Wijen \& Tulder, 2011). All this sets a limit to environmental policy along with the pressure of stakeholders in the design of regulations and in the management of the different regulatory and territorial bodies. The deterioration of strategic water resources has led the Constitutional Court to mandate that these be defined as subjects of rights, ordering the various institutions to take coordinated action to protect them (Sentence 622 de 2016). ${ }^{1}$

\section{Water environmental policy in Colombia}

Water environmental policy can be analyzed based on the restrictions faced by firms that create impacts on water resources. When water taken directly from natural sources is used in production, firms must allocate $1 \%$ of their investments for recovery, preservation, oversight of the watershed and a closure plan. Although it is impossible to leave the site exactly as it was found when the activity began, it should be left such that in a "reasonable" period, it will recover (Decree 1541 of 1978). In addition, firms must make compensation plans for one unit of new coverage for each affected unit and between two and eight trees planted for each tree cut down following Resolution 1503 of 2010 by the Ministry of the Environment and Sustainable Development (MADS), which presents the method to perform environmental impact studies, showing that "in order to compensate for the impact generated, it is necessary to compensate an equivalent ecosystem." And while a firm must have an environmental license and there are various methodologies for that (Resolution 1478 of 2003) (MADS, 2010), conflict resolution by judicial organizations has not been possible given the lack of criterion unity, the subjectivity of environmental evaluation, and implementation difficulties. ${ }^{2}$

\section{Information systems and territorial organization}

\footnotetext{
Another limit is the scope of regulatory institutionality as there are ways of organizing water use and providing aqueducts. These abound in rural areas and coexist with agribusiness, and with public utility companies where these do not have coverage. There is a tension between the state force that seeks to institutionalize these ways that escape compliance with regulation and the market logic of giving water a price, and which can be more effective in achieving cooperative solutions (community water self-management). Institutionality has made positive progress in universal access to the resource by ensuring a vital minimum and for the most vulnerable not to be cut off when they do not pay; actions that have been promoted by citizen mobilizations (Water Referendum) (Moncada et al., 2013). However, increasingly scarce water quality and quantity increase illegal and violent appropriations of the resource that violate the constitutional right to water use by anyone who requires it (Guerrero et al., 2016).

${ }^{4}$ Also, anyone who does not comply with legislations in force incurs sanctions between 140 and 50000 legal minimum monthly wages, prison sentence of 55 to 112 months and additional administrative sanctions (article 34 of the Criminal Code - Law 1453 of 2011).
} 
From the regulator's perspective, the environmental policy can be classified in terms of information systems, CAC policies, and economic instruments. The first are the basis for both the knowledge of economic actors and the organization and administration of a territory, as well as regulation and oversight, environmental auditing, and control. They include the Water Resource Information System (Decree 1323 of 2007), the models for classifying priority implementation zing watersheds, and calculating groundwater scarcity, and actor registries (Decrees 303 of 2012 and 1324 of 2007). ${ }^{3}$ They also include the limiting of riparian buffer zones and protected areas or afferent conservation areas, watershed and aquifer planning, policies and regulations on land use, control and monitoring systems on the quality of water for human consumption, among others.

Water resource management has its origins in Decree 1381 of 1940, but it was made concrete through Decree-Law 2811 of 1974, which defines a watershed as a "special management area" and establishes that "watershed management is understood as the planning of coordinated use of the land, water, flora, and fauna, as well as the execution of projects and treatments." Through Law 99 of 1993, which created the MADS as the body responsible for overseeing the management of the environment and renewable natural resources, the National Environmental System (Sistema Nacional Ambiental) was appointed to set guidelines for watershed management, as well as the scope of the CARs in managing the watersheds in their authority. In 2010, the MADS issued the National Integrated Water Resources Management Plan (PNGIRH), defining watersheds as special units in which water interacts with other renewable natural resources, ecosystems, and anthropogenic actors (public organizations and residential, industrial, and commercial users)

Law 1523 of 2012, which adopts the "National Disaster Risk Management Policy" and establishes the National Disaster Risk Management System (SNGRD), ordered that CARs must support territorial entities within their authority by integrating them into the WMPs. Decree 1640 of 2012 implements the instruments for planning and managing watersheds, aquifers, and others, supplying greater clarity in the CARs' management and the different responsible entities and actors. In addition, municipalities must incorporate the conditions of these WMPs into their LMPs.

Finally, Decree 3600 of 2007, which regulates Law 388 of 1997, considers restrictions on human settlements and the possibility of urbanizing an area if it is protected as rural land (conservation and environmental protection areas, agricultural and fishing production, cultural heritage, public utility services, among others).

Table 1: Main instruments for managing renewable resources to be considered in WMPs

\begin{tabular}{|c|c|c|}
\hline Level & Type & Instruments \\
\hline National & Planning & $\begin{array}{l}\text { - Strategic plans in macro river watersheds } \\
\text { - Environmental zoning of forest reserves (Law } 2 \text { of 1959) } \\
\text { - Protected area management plan }\end{array}$ \\
\hline Regional & Planning & $\begin{array}{l}\text { - Ens for: } \\
\text { areas, moors, wetlands, and swamps } \\
\text { - Management of water and forest resources } \\
\text { - Environmental and action plan of the Urban Environmental } \\
\text { - } \quad \text { Studhorities } \\
\text { conses to name strategically important ecosystems for } \\
\text { - Other planning instruments on natural renewable resources }\end{array}$ \\
\hline $\begin{array}{l}\text { Regional or } \\
\text { Local }\end{array}$ & Administrative & $\begin{array}{l}\text { - Economic: } \\
\circ \quad \text { Tax for water use } \\
\circ \quad \text { Environmental tax } \\
\circ \text { Environmental fine } \\
\circ \text { Payment for environmental services } \\
\circ \quad \text { Tax incentives } \\
\text { - Regulatory: } \\
\circ \quad \text { Regulation of water use } \\
\circ \quad \text { Environmental licenses, concessions } \\
\circ \quad \text { Discharge permits } \\
\circ \quad \text { Demarcating riparian buffer zones } \\
\text { - Financial: Transfers from the electrical sector; Territorial } \\
\text { Entities must invest } 1 \% \text { of their budget; Tax: income, } \\
\text { national and local funds. } \\
\text { - Information: information and registration system for water } \\
\text { resource users. } \\
\text { Monitoring: monitoring of policies, plans, programs, and } \\
\text { projects; regional monitoring program for water resources. }\end{array}$ \\
\hline
\end{tabular}

Source: (MADS, 2014)

In December 2015, the Law on Areas of Interest for Rural, Economic, and Social Development (ZIDRES) was approved.

${ }^{5}$ The demarcation of the Santurbán Moor stands out, as it is a point of reference for the declaration of other moors. Constitutional Court decision C-035 of 2016, which prohibits mining in moor areas, and C-367 of 2011, which modified the Mining Code (Law 685 of 2001), extended mining exclusion areas (natural parks, forest reserves, moors, and wetlands). Territorial entities must invest $1 \%$ of their income in increasing the offering of strategic areas (Decree 1900 of 2006 ) and areas of interest for aqueducts (article 11 of Law 99 of 1993), along with the investments made by the CARs, which are territorial organizations responsible for applying environmental regulations defined by the MADS at the central level. The serious problem is that other economic resources are required to the effectiveness of control and management. 
This law looks to develop areas that demand inflated costs for productive adaptation, have low population density and extreme poverty rates, and lack transportation and product commercialization infrastructure, such as waste-land areas. These projects must be registered in the MADS and follow LMPs and Basic Land Management Plans (PBOTs) with property productive and social management criteria defined by the Agricultural Rural Planning Unit (UPRA). This has created some controversy since, in addition to promoting land concentration, if the projects do not follow these plans, environmental sustainability can be affected due to the fragility of some areas such as high plains and the large-scale projects being promoted (El Espectador, 2015).

\section{Water Use Tax (WUT)}

The WUT is charged for the use of water from a natural source and is subject to a water concession (Decree 2811 of 1974). It is a management instrument for conservation and efficient water use, and a financial source of investments to guarantee its renewability.

The value to be paid $(V p)$ is calculated as:

Vp $=$ Fop.WUT.v

where Fop is a factor of opportunity cost, $v$ is the volume of water; in turn, the WUT is defined as follows:

$W U T=F_{R} T_{\text {Min }}$

$T_{\text {Min }}$ is the minimum tax defined by the MADS, $F_{R}$ is a regional factor calculated by the respective RAC.

$F_{R}=1+[C k+C e] \cdot C s$

where $C k$ is an investment factor, which should add the total costs of the LMP and the WMP not included in the $T_{\text {Min }}$ and the largest limit of seven to twelve for groundwater and surface water, $\mathrm{Ce}$ is the scarcity index of the watershed, and there is a socioeconomic factor $(C s)$, calculated using the Unsatisfied Basic Human Needs (UBN). ${ }^{4}$

However, Decree 4742 of 2005 established that for $2006 \mathrm{WUT}=T_{\text {Min }}=U S D \$^{0.00016} / \mathrm{m}$ 3, arguing a foundation in Resolution 240 of 2004 "based on an estimated average per cubic meter of the annual investments in which the competent environmental authorities have participated in the last three (3) years for the effects of preventing or controlling depreciation of the resource," and for 2007-2017, it defined the Unit Tax for water use (UT (Unit Tax)), instead of the WUT (Water Use Tax), as follows:

$U T_{t=} U T_{t-1 \cdot}\left(1+X_{t}\right) \cdot\left(1+I P C_{t-1}\right)$

where $X_{t}$ is a factor of real increase calculated as follows:

$X_{t}=\frac{\sqrt[n]{W U T_{t-1}}}{U T_{t}}-1, n=2017-\mathrm{t}$ and $W U T_{t-1}=F_{R} \cdot T_{\text {Min }}$

Finally, beginning in 2017, the $U T_{t}=W U T_{t}$. The Fop considers whether the user creates opportunity costs for consumers downstream (Decree 155 of 2004) and is calculated as follows: $F_{o p}=\frac{V_{c}-V_{v}}{V_{v}}$ for those who return the water to the same watershed or hydrological unit. $F_{o p}=1$, in other cases.

The Fop $\in(0,1)$ and relates only catchment volume $(V c)$ and discharged volume $(V v)$. In addition, a consumer can stock from multiple sources and discharge in a single source, which would express that $V v>V c$, with an extremely low Fop and a lesser value to be paid. It is also probable that the consumer may have been granted several water catchment and

${ }^{6}$ As Cs $=(100-\mathrm{UBN}) / 100$ it would attract consumers of water that would encourage employment in less developed areas. 
discharge permits, which imply a different cost, but make it possible to add up all catchment and discharge costs and find a single Fop. It is also possible that some discharge volumes may not be declared, or that groundwater catchment is carried out with no later discharge in watersheds, causing changes in the value to be paid. And, unfortunately, the Fop is unrelated to the use made of the resource or the opportunity cost of not having it. As a result, in Colombia, negligible amounts are charged for water use, although new regulations are expected to increase its value. ${ }^{7}$

\section{Electricity Sector Transfers (ESTs)}

Electricity Sector Transfers are a tax for water use which substitute payment of WUTs by hydroelectric power generators with an installed capacity greater than $10000 \mathrm{~kW}$ (Article 45 of Law 99 of 1993 and Decree 1933 of 1994) and are equal to $6 \%$ of gross electricity sales, the result of multiplying the amount generated by the block sales rate calculated by the Gas and Energy Regulation Commission (CREG). These transfers are distributed among the municipalities that provide or hold a reservoir (3\%) and the CARs in authority $(3 \%)^{5}$ OBJ The former must be earmarked for projects including priorities of basic sanitation and environmental improvement in their development plans; only up to $10 \%$ should be assigned to functioning ${ }^{6} O B J$ CARs contributions are allocated to environmental protection and defense of the watershed and the hydroelectric project's area of influence.

Debates on this tax suggest it should be extended to hydroelectric plants with a capacity between 500 and $9999 \mathrm{KW}$, which should pay $5 \%$ of their gross sales; the National Parks should receive the income given that in their jurisdiction there are also supplier watersheds; and the tax should be raised to $7 \%$. While gross sales are an amount that discounted from the transfer of some payments made by the generators for the price of financing equity funds in the electrical sector and the administration and regulation of the electrical system, there is an even greater difference between the spot price of electricity and the gross sales value, where the opportunity benefits for water use are not transferred, especially when the spot price increases abruptly in anticipation of situations of water scarcity.

\section{CAC Policies}

Some indices have been developed to reduce the lack of available information and figure out a way the identify of changes in water quality in cases of discharge. The National Sanitation Foundation Water Quality Index (NSF-WQI) presented by Brown et al. (1970) suggests that 9 of 44 substances should be included in it. ${ }^{10}$ Despite the ease of using an index, the non-specificity of components leads to mistaken conclusions. For example, if eight obtain scores greater than zero but the $\mathrm{pH}$ obtains an extremely low value, the global index will be "good," but a body of water with an extreme $\mathrm{pH}$ value will not be able to support certain forms of aquatic life or productive and recreational activities (Wills and Irvine, 1996).

In Colombia, CAC policies include some of the NSF-WQI and Pratti Index ${ }^{11}$ components such as BOD5, pH, temperature, and TSS (Total Suspended Solids). The others are subject to analysis and report by the CARs. These norms date from Decree 1594 of 1984 and were updated by Resolution 631 of 2015 of the MADS. ${ }^{12}$ This decree set up discharge limits as a total percentage of pollutants (Table 2). It also distinguished between new and existing users, being laxer with the latter, and determined fixed values for cyanide, mercury and lead, among others. The percentage removal of $80 \%$ is not arbitrary but follows a technical study that showed if an environmental tax of USD $\$ 100 /$ ton were set up, industries would seek to reduce their discharge by $80 \%$ (The World Bank, 1999).

\footnotetext{
7 In Ecuador \$0.11009 is charged per m3; in Peru, USD\$ 0.01573; and in Brazil, USD\$ 0.17300 (2015 COP).

8 Thermoelectric plants are charged $4 \%$ of electricity sales, distributed into $2.5 \%$ for the RAC and $1.5 \%$ for the municipality where the plant is located.

9 It has been found that municipalities allocate many of these resources for other purposes' including fiscal consolidation' public debt' electrification' and others; they are diverted for councilor pay' life insurance' fuel, and automobile fleet maintenance- Recommendations include applying management indicators associated with environmental results and basic sanitation and making municipal fiscal effort a condition for access to the ESTs (Hernández et al., ${ }^{2010}$ ). Decree ${ }^{4629}$ of ${ }^{2010}$ dictates that municipalities must allocate these resources to investments that counteract and mitigate disaster situations and social' economic' and ecological emergency situations caused by winters that lead to the intervention by the central government.

10 The components and their weights are: $\mathrm{O}^{2}{ }^{(0.17)}$, fecal coliform ${ }^{(0.15)}, \mathrm{pH}^{(0.12)},{ }^{5}$-day biochemical oxygen demand (BOD) (0.1), $\mathrm{Nitrate}^{\left(\mathrm{NO} \mathrm{O}^{3)}(0.1),\right.} \mathrm{phosphates}^{(0.1)}$, temperature ${ }^{(0.1)}$, turbidity ${ }^{(0.08)}$, and total suspended solids (TSS) (0.08).

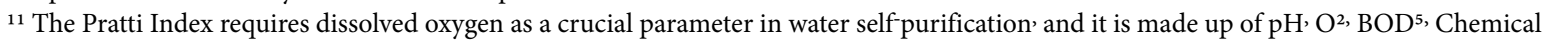
Oxygen Demand (COD), TSS, Ammonia' $\mathrm{NO}^{3}$, and Chlorine

${ }^{12}$ Previously' Decree ${ }^{1594}$ had been modified by Decree 3930 of 2010 of the Presidency and Decree 4728 of 2010 of the MESD
} 
Table 2: Parameters for discharge into superficial bodies of water

\begin{tabular}{lll} 
Reference & Existing user & New user \\
PH (units) & 5 to 9 & 5 to 9 \\
\hline Temperature & $40^{\circ} \mathrm{C}$ & $40^{\circ} \mathrm{C}$ \\
\hline Floating material & Absent & Absent \\
\hline & Removal \\
\hline Fats, oils, and grease & $80 \%$ & $80 \%$ \\
\hline TSS & $50 \%$ & $50 \%$ \\
\hline BOD5 & & \\
\hline Domestic waste & $30 \%$ & $80 \%$ \\
\hline Industrial waste & $20 \%$ & $80 \%$ \\
\hline
\end{tabular}

Source: article 72 of decree 1594.

In general, Decree 1594 allows discharge of liquid waste that does not correspond to the set of the characteristics of water bodies, such as flow rate and volume, but the pollutant change taken on by a water body, and it is incomplete since it does not set global maximum pollutant loads. Resolution 631 tried to resolve these issues, but it also has several problems: 1. The majority of parameters are subject to analysis and report, such that lower costs are incurred when each of them are specified, though the polluting actor must be the one to report information to the environmental authority, and the latter must input it in the Water Resource Information System or WRIS); 2. It also does not contemplate maximum loads, so, it is possible to discharge as many liters of water as are desired, as long as the parameters per liter are complied with; it is therefore important to review the possibility of establishing global limits. 3. Since micrograms per liter (mg/l) are regulated, the restrictions can be followed by diluting the pollutant load in a greater quantity of water, which motivates greater water use. 4 . The parameters are not comparable with earlier regulation, which set up a discharge percentage ( $80 \%$ on the average) instead of absolute values. The latter are more restrictive for large polluting firms (Peláez, 2015). However, in general equilibrium exercises, it has been concluded that if these values are not reviewed over time, they will be more permissive than the earlier regulation (Tobón et al., 2018).

Regarding discharge of combined waste from two independent activities, agriculture and fishing, with the most restrictive values being applied to each reference; pollutant control for agrochemical use. In addition to complying with the measures demanded by the CARs, it prohibits: 1 . Their manual application within a buffer of three meters measured from the shores of any body of water and 2. Their aerial application within a buffer of 30 meters is also measured from these shores. Regarding pesticides, the contents of Decree 1843 of 1991 of the Ministry of Health are considered.

For land agrochemicals, Colombian Technical Regulation (NTC) 5167 of the ICONTEC establishes that compost must not be used for agricultural purposes since its components are bio accumulative and soak the soil, unless they follow the parameters approved. This standard sets the criteria for controlling superficial water discharge from agricultural activities, supplying a list of 21 parameters that are not comparable to the earlier norm except for $\mathrm{pH}$, which follows Decrees 1594 of 1984 of the Ministry of Agriculture and 631 of 2015 of the MADS. In addition, the NTC suggests evaluating other substances, such as phosphorus and nitrogen, bases for the component's phosphate and nitrate, which are suggested in the NSF-WQI.

Regarding the progressive deterioration of water resources (IDEAM, 2014), Resolution 631 of 2015 was passed to regulate article 28 of Decree 3930 of 2010 and update Decree 1594 of 1984, modifying measurement of pollutant discharge and specifying parameters per economic activity ( 73 activities and 8 sectors).${ }^{13}$ Measurement must be completed in terms of the number of pollutants per liter of water discharged, considering $\mathrm{pH}, \mathrm{COD}$ (Chemical Oxygen Demand), BOD5, TSS, sediment solids, and fats, oils and grease. ${ }^{14}$ The concentration of polycyclic aromatic hydrocarbons must be less than or equal to $0.01 \mathrm{mg} / \mathrm{L}$, and for some economic sectors exist additional parameters. For temperature, the criterion of $40^{\circ} \mathrm{C}$ is kept, but requirements are extended since the difference in values between the mixing area and the body of water before discharge must not be greater than $5^{\circ} \mathrm{C}$.

Finally, according to the Contraloría General de la República (2015), Resolution 631 is not as strict as others worldwide. ${ }^{15}$ Recommendations include implementing measurements for types of water flows based on the Brazilian experience since smaller firms have greater BOD5 and COD levels and could support a greater quantity of TSS or creating a hybrid in percentage and fixed terms with a maximum superficial water discharge concentration and a minimum reduction

13 Given that agricultural activities are partially considered by Decree 631 (it only includes agro-industrial activities), they must be regulated by the Ministry of Agriculture and the technical standards of ICONTEC mentioned above.

14 This regulation also includes total hydrocarbons' orthophosphates' and others.

${ }^{15}$ Of the 9 parameters suggested in the NSF-WQI, only 2 are considered and their weights are not significant on the index 
percentage and considering the location of the discharge site into water bodies, as in the European Union.

\section{Environmental compensatory tax}

This tax complements the CAC policies, and therefore there is a hybrid system in Colombia: a tax is levied on some regulated discharges, founded in Law 99 of 1993 in article 42 as follows:

Direct and indirect use of the atmosphere, water, and land in order to introduce or dump refuse or agricultural, mining, or industrial waste, wastewater, or sewage of any origin, smoke, fumes, and harmful substances resulting from anthropogenic activities or activities created by mankind, or economic or service activities, whether for profit or not, shall be subject to the payment of environmental taxes for the harmful consequences of the said activities

The goal is to give cues to change consumption and production patterns and make decisions following the social and environmental costs of pollution, as well as to incentivize changes toward cleaner technologies. Its background includes Presidential Decrees 2811 of 1974 and 1594 of 1984. It was centered only on for-profit activities, excluding public utility services for aqueduct and sewer firms in financial trouble, and payment depended on the cost of the monitoring and control programs for the CARs. After Law 99 of 1993, the tax was transformed by a clearer economic incentive (Restrepo, et al, 2007). ${ }^{16}$

For each of the seven parameters subject to taxation, the CAR should set up an environmental compensatory tax rate which is the result of multiplying the smallest rate $(T m)$ by a regional factor $(F R)$ :

$M P=\sum_{i} T m_{i} * F R_{i} * C_{i}$

where:

$M P$ : Amount to be paid ${ }^{17}$

Cí: Pollutant load from parameter $i$

The Tm was set up by Resolution 273 of 1997 and updated by Resolution 372 of 1998 of the MADS. However, there are only two parameters subject to charge; TSS and BOD5 and it must be updated with the annual CPI (Consumer Price Index).

Decree 2667 of 2012 of the MADS establishes that the following parameters must also be checked: temperature, COD, dissolved oxygen, fecal coliform, and pH. This choice is taken from the NSF-WQI and some firms have made complaints about it and the respective caps, arguing that the method applies to the characteristics of water bodies and rivers in the United States in the 1970s without an understanding of the particularities of Colombia (Consejo de Estado, 2007). However, neither a $T m$ nor an $F R$ has been set up for these new parameters. It is also important to mention that according to the NSF-WQI, dissolved oxygen is more important than BOD5, and sand turbidity is more important than TSS (Abbasi and Abbasi, 2012).

The FR aims to multiply the smallest Tm rate such that it represents social and environmental costs of discharge. This is calculated by the CARs according to global and individual quality goals and was proposed by the rescinded Decrees 901 of 1997 and 3100 of 2003. Its evolution has been as follows:

Article 9 of Decree 901 proposed that the CARs must see ${ }^{18}$ an increase in the $F R$ "until reaching a regional rate level that causes a reduction in the total pollutant load that meets the pre-established level for the reduction goal" and beginning at 1 and increasing 0.5 each semester. The CARs stopped increasing the FR as goals were reached. The clarification of article 10 states that, in any case, the amount to be paid: "includes the value of depreciation of the affected resource, considering

16 See decrees 901 of 1997 and 3100 of 2003 of the MESD (modified by Decree 3440 of 2004), which regulated levying of environmental taxes and set the procedure for the minimum rate' regional factor' reduction goals, taxable entities, collection mechanisms, oversight and control and complaints

17 The allocation of these payments shall be up to $10 \%$ to RACs to cover costs of tax implementation and monitoring, and the remaining $90 \%$ for investment projects in water decontamination and monitoring water quality ${ }^{15}$ Of the 9 parameters suggested in the NSF-WQI, only 2 are considered, and their weights are not significant on the index 
the social and environmental costs of the damage stated in the pollutant load reduction goal. Likewise, the costs of resource recovery are reflected in the minimum rate $(\mathrm{Tm})$." Despite its conception within the decree, the environmental compensatory tax abandons the spirit of Law 99 since in its regulatory evolution it has moved away from the concept of social and environmental costs.

Five years later, Article 15 of Decree 3100 of 2003 updated the Fr method beginning with a value equal to one, adjusting it annually beginning at the end of the second year and applying the following to actors who did not meet the goal:

$$
F R_{t}=F R_{t-1}+\frac{\left(C C_{t}-C C M_{t}\right)}{\left(C C L t-C C M_{t}\right)}
$$

where:

$F R_{t}:$ Adjusted regional factor.

$F R_{t-1}$ : Previous year's regional factor.

$C C_{t}$ : Total pollutant load received by the river, water body or section in $\mathrm{kg} / \mathrm{year} .{ }^{19}$

$C C M_{i}$ : Global pollutant load goal in kg/year.

CCLt: Total pollutant load in $\mathrm{kg} /$ year.

At the end of the five-year period, if the goal was reached, FR begins at 1; if not, it begins at the value at which it ended the earlier five-year period. In any case, $1 \leq \mathrm{FR} \leq 5.5 .^{20}$ Formula (6) would be evaluated again at the end of the second year of the new five-year period, updating the variables $C C L$ and $C C M$.

Finally, Decree 2667 of 2012 changed the formula for $F R$ as follows:

$$
F R_{t}=F R_{t-1}+\frac{C C_{t}}{C C M_{t}}
$$

The global goals require a consultation for BOD5 and TSS as follows: baseline, projections of user load and quality goals in force at the end of the five-year cycle, the body of water's ability and execution of works included in the Sanitation and Discharge Management Plan (Discharge Permit, and Plan for Reconversion to Clean Technology and Discharge Management, goals per user based on their own loads, and global goal). In addition, group goals may be defined for users who share or do not share the same economic activity.

Article 184 of Law 1607 of 2012, which changes the Colombian tax code, obligated state institutions to perform a study on the effectiveness of these taxes, as well as the identification and viability of new taxes. It is worth noting that during 2008-2012, the 39 CARs levied environmental compensatory taxes, either with only $T m$ (57.9\%) or applying the FR (44\%), and $43 \%$ were implementing the process of calculating $F R$ for 368 water bodies ( $52.6 \%$ of the total). Of $21.2 \%$ of the water bodies in which the environmental tax with $F R$ was charged, it was above 1.00, which shows global goals for pollutant load are not followed, while $20.9 \%$ of these show compliance $(F R=1)$ (Contraloría General de la República, 2014).

Recommendations include strengthening charges since collection is less than what is billed; and improving information given that it is not only incomplete, but also incorrect for many of the CARs. The environmental compensatory tax also requires updates in all the parameters presented by the new regulations and the specification for goal loads for the regional factor, which are lesser or equal to those set up in the regulation.

Since the Tm was approved in 1998, the value has barely surpassed the negligible threshold of USD $\$ 0.03145$ per $\mathrm{kg}$ of pollutant load (BOD5). The Tm for 2015 is USD $\$ 0.03864 / \mathrm{kg}$ for DBO5 and USD $\$ 0.01653 / \mathrm{kg}$ for TSS (MADS, 2015). In addition, of the seven parameters to be measured, only TSS and DBO5 are charged, leaving out critical variables such as temperature, $\mathrm{pH}$, dissolved oxygen, and turbidity.

The CARs' behavior can be explained by the funding sources since the environmental tax is the one that generates the least

\footnotetext{
18 Not every year, as currently occurs in accordance with Decree 2667 of 2012.

${ }^{19}$ Not including the reduction goal of sewerage firms

${ }^{20}$ This limit is due to a technical issue regarding the assimilation capacity of bodies of water for discharges (Uribe, 2016; Naranjo, 2016).
} 
income ( $0.03 \%$ of total income on the average). Other sources such as participation in property taxation (environmental surcharge), electricity sector transfers, issuance of environmental licenses and the imposition of fines generate a large part of their income (Sánchez, 2011). Finally, there exists the possible interference of interest groups, particularly polluting firms, in the social agreement required by the goals, and of political parties in the makeup of the CARs.

\section{Payments for environmental services (PES)}

Another economic instrument is PES, which can be understood from different viewpoints ranging from environmental to ecological economy, from paying for the opportunity cost of the individual that offers them to a symbolic value when the service is considered a social contribution (Tacconi, 2012). The main problem lies in calculating that range of value and the social utility generated by said services. In addition, payments tend to be limited to one of the several environmental services provided by a natural system; for example, when only $\mathrm{CO} 2$ catchment provided by a forest is paid for, there is another benefit of water regulation that is not being paid for.

Another problem with PES is their financing as public goods since those who pay for them help other users who do not have to pay. Therefore, there are incentives to free-rider behavior and the resulting allocation will be smaller than socially desired. Therefore, since PES are private initiatives, there are intentions to increase them through public policy. For example, in Colombia, tax subsidies are awarded to those who demand them or substitute closure plans that must be prepared by firms that have an impact on the environment (see Decree 1007 of 2018 of the MADS and 953 of 2013 of the Presidency).

It is common in Colombia to sign contracts with the provider of an environmental service for up to five years, in which awareness is raised to keep habits of environmental protection. From the outset of the contract, the offeror is notified that he or she will receive an economic incentive for practices that he or she should already be undertaking given that many are approved by environmental regulations but are not enforced by the regulator, for example, respecting 15 meters around bodies of water. Therefore, another characteristic of these services in Colombia is that they help with compliance with environmental regulations, which are not followed due to the technical difficulties and the costs of carrying out this function. At the end of the five-year period, an evaluation is made of whether the practices are sustainable or whether the economic incentive is still necessary, and if so, the contract is renewed for a reasonable period.

Examples of PES include rural aqueducts, in which beneficiaries finance the protection of water reservoirs, and the Ecoversa and Patrimonio Natural funds, which negotiate directly with the owner of the service site, such that a minimum value is paid to him or her. In the case of the fund $\mathrm{BanCO} 2$ for Eastern Antioquia, firms and even consumers may pay for the service of $\mathrm{CO} 2$ catchment achieved by strategic forests, and the product of each tree and the number of trees per hectare are valued as shown by the global carbon market. In addition, the program is reinforced by the environmental corporation CORNARE since it is a substitution mechanism to compensate for trees cut down, giving firms corporate social responsibility certificates. As of 2015 , USD $\$ 62.9$ are paid per hectare, although the payment has a limit of USD $\$ 188.7$ independently of the number of hectares and for an unlimited time. In addition, it is concentrated in a special population such as those with extremely low income or those displaced by the armed conflict. This type of mechanism is also being applied in the RioGrande watershed in northern Antioquia through the Cuenca Verde initiative, in which the owners of the lands reserve an area for protection or reforestation and are compensated with technical aid, the installation of wastewater treatment plants, the building of restraining walls in threatened areas, the installation of energy saving stoves, the building of orchard sheds and reforestation on the banks of water bodies.

\section{Tax incentives}

Through the approval of Law 99 of 1993, the Ministry of the Environment is in charge of promoting plans for industrial restructuring ${ }^{21}$ as well as the economic instruments analyzed. ${ }^{22}$ These actions have been included in international initiatives such as the global carbon market whose goal is to help mitigate climate change. ${ }^{23}$ Another action is the creation of Green Markets, which seek to attract demand with environmental sensitivity. A firm considered to be green is certified through the ICONTEC, which shows that the firm sustainably uses resources, renewable energies, recycling policies, and cleaner technologies. They are also subject to tax benefits.

21 This is what is known in the literature as changing the production process, contrary to the use of end of pipe technologies, in which the production process is maintained but filters or treatment plants are added at the end of the production process- The former is more efficient for achieving environmental goals but is more costly and provides uncertain results. 
Tax exemptions and exclusions applicable to the acquisition of reduction technologies and investment in research that favors innovation in clean production processes fall within the framework of tax legislation (Law 6 of 1992 of Congress), article 123 of which sets up deductions for investments in control and improvement of the environment. Article 158 and the following articles of the Tax Code establish that "legal persons who make direct investments in control and improvement of the environment shall have the right to annually deduct from their income the value of said investments which have been made in the respective tax year. The value to be deducted for this reason shall in no case exceed twenty percent $(20 \%)$ of the taxpayer's taxable income determined before subtracting the value of the investment." In addition, deductions are granted on income taxes for investments in research, technological development, and innovation, as well as control and improvement of the environment. For example, projects carried out through research and technological development entities recognized by the Ministry of Science and Technology may deduct from its income 175\% of the investment in said projects with a limit that may not exceed $40 \%$ of taxable income determined before subtraction of the investment.

Decree 722 of 2014 of the Ministry of Finance, which updates the goods excluded from the VAT tax, previously established by Laws 1607 of 2012 and 223 of 1995 of the Congress and the Tax Code, sets up a competitiveness factor in the production sectors, such as food with agricultural origins and its production inputs. The tax code shows that importation of machinery not produced in Colombia for the following activities does not incur sales tax: garbage and waste recycling, wastewater purification and treatment, atmospheric emissions or solid waste, river recovery and basic sanitation, as well as importation of equipment for environmental control and monitoring included in the Montreal Protocol on substances that reduce the ozone Layer. This imported machinery must stay during its service life unless it is transferred to a leasing company.

These incentives promote importations that will help move toward cleaner production and the exportation of goods with an added value. However, firms show their contempt for being subject to the implementation of environmental goals agreed upon with the Ministry of the Environment and the plans and programs of the Ministry of Mines and Energy, which are, in turn, subject to budget availability in the Medium-term Fiscal Framework and other restrictions reported by the Ministry of Finance. The above causes high uncertainty: for example, regarding some plans such as the one for energy and environmental efficiency administered by the Mining Energy Planning Unit (UPME), which is part of the Ministry of Mines and Energy, only 50\% of the projects presented were approved (UPME, 2015). In addition, firms that belong to the small and mid-sized sector do not pay high income taxes, so they could not take advantage of discounting those investment payments made for pollution reduction technologies (Supersociedades, 2015). Finally, accessing these incentives is exclusive of firms formally set up, which can imply greater costs that could not be justified by the expected benefits.

\section{Discussion and final remarks}

In Colombia, there is progressive deterioration of water resources resulting from growing population and economic dynamics. However, there are also failures in the regulation of water production and consumption activities. Commitment to have more legislation is the most common response but also the most ineffective. Since it has been shown that the normative architecture to regulate water resources is comprehensive, Colombia should not follow the easy route of redefining goals or new regulations; the better path is to improve or enforce existing regulations. Hybridization between CAC policies and economic incentives has another attribute that makes them more effective in the current circumstances where there is an increasing political and social sensitivity to economic adjustment measures in emerging countries (Monahan, 2019), because it has greater social approval given the fixed part of the regulation (CAC policies), which has the attribute of ensuring minimal protection of water resources, albeit with higher costs of regulatory intervention.

\footnotetext{
22 Technical regulations mainly include sector orientations and the National Centers for Cleaner Production and Environmental Technologies (CNPMLTA).

${ }^{23}$ The goal agreed upon in the COP 21 (December 2015) of increasing temperature by ${ }^{\circ} \mathrm{C}$, and the additional efforts to try to limit it to ${ }^{1.5{ }^{\circ}} \mathrm{C}$, depend on the implementation of the Paris Agreement in 2020. All the signatory countries must limit their greenhouse gas emissions although developed countries will have to make a greater effort and mobilize at least USD $\$ 100.000$ million annually to contribute to an adaptation and energy conversion fund for developing countries and those most vulnerable to climate change. Colombia's position is complex given that it has gone from being an underdeveloped country which could previously sell emission reduction efforts below the MDL, to being one with a medium income and which must comply with environmental goals of reducing emissions by ${ }^{20 \%}$ in ${ }^{2030}$, based on pollution levels in 2010. In addition, it is on the list of most vulnerable countries to climate change' meaning that the establishment of goals and carbon taxes are required, but that it also hopes to benefit from said fund.
} 
Some suggested improvements to the set of CAC policies may be: land use management should consider information restrictions and the priority of water resources; water use taxes should be similar to those in other countries in the region or be related to the benefits of using the resource, as occurs with the significant income transfers made by hydroelectric producers; environmental compensatory taxes should abide by the spirit of Law 99 of 1993 and be comparable in their parameters to the new discharge regulations such that this hybrid environmental policy can function as a safeguard against the risk of greater environmental deterioration and provide minimal signals to modify patterns of consumption and production, and economic decisions should be made according to the social and environmental costs of pollution; changes should be incentivized toward cleaner technologies; or greater use should be made of tax subsidies to consider the option of a financial sustainability in the sense that subsidies should come in some percentage from the collection of environmental taxes. There should also be private mechanisms like PES, although so far, they have been incentivized by public policy, their scope is limited, and payment made for them does not compensate for the opportunity cost of the various ecosystem services that can be preserved.

Adjusting water use and environmental compensatory taxes would be expensive, and most agricultural production has a remarkably high subsidy implicit to the use and contamination of water. General equilibrium models applied to Colombian water resources estimate that adjusting countervailing rates to the social cost of pollution would significantly increase environmental compensatory taxes, causing higher prices on essential foods such as milk (Tobón, Molina \& Vasco, 2018). Under current and medium-term conditions, where there will be other priorities such as poverty alleviation and economic growth recovery, it will be more difficult to resort to the use of economic instruments. It is therefore recommended that tax adjustments supply a minimal sign of scarcity, such as that needed for the operation of regulatory bodies.

In any case, this institutional adjustment must consider the influence exercised by interest groups and the administrative and technical capacities of the regional corporations (CARs) to apply regulations, which means increasing their autonomy and their access to greater resources, for example by limiting the influence of political parties in their makeup, making their budget more dependent on the collection of environmental taxes, and requiring that monitoring and control of compliance with regulations be financed by regulator actors. The budget flexibility of these bodies should also be considered since they have fixed income regardless of efficiency in their regulatory management, in addition to assigning regulatory management costs to regulated firms as the tasks of regulatory bodies are increasing, making them impossible to accomplish given the limited resources they have.

Finally, the regulation of water and other environmental goods and services is intricately linked to that of greenhouse gases. And facing climate change implies a more comprehensive regulatory evolution in terms of CAC policies, promotion of unconventional energy sources, rational and efficient use programs, tax benefits and carbon markets. This regulatory evolution is linked to the commitments that Colombia must meet under the Kyoto Protocol. As there are complementarities between reducing GHGs and efficient use of water resources, water regulation is expected to be part of a large umbrella program that has as its central focus the fight against climate change.

\section{References}

1. Abbasi, T., \& Abbasi, S. A. (2012). The Biotic Indices. In Water Quality Indices (pp. 219-247). Doi: $\underline{10.1016 / \mathrm{b} 978-0-444-54304-2.00013-0}$

2. Bergek, A., \& Berggren, C. (2014). The impact of environmental policy instruments on innovation: A review of energy and automotive industry studies. Ecological Economics, 106, 112-123. Doi:10.1016/j. ecolecon.2014.07.016

3. Blackman, A. (2009). Colombia’s discharge fee program: Incentives for polluters or regulators? Journal of Environmental Management, 90(1), 101-119. Doi: 10.1016/j.jenvman.2007.08.010

4. Botero, R. (2017). Marco legal del control fiscal ambiental en Colombia. Contraloría General de la República de Colombia [WWW Document]. http://media.utp.edu.co/centro-gestion-ambiental/archivos/mod-vanalisis-macroeconomico-ambiental/02marcolegaldelcontrolfiscalambientalencolombia.pdf 
5. $\quad$ Brown, R., McClelland, N., Deininger, R., y Tozer, R. (1970). A Water Quality Index- Do We Dare. Water Sew. Work. 117(10), 339-343.

6. Contraloría General de la República - Contraloría delegada para el Medio Ambiente (2015). La sostenibilidad ambiental en el Plan Nacional de Desarrollo: avance o retroceso. Economía colombiana, 344, 67-75.

7. Contraloría General de la República (2014). Informe del Estado de los Recursos Naturales 2012/2013. http://campusvirtual.contraloria.gov.co/campus/5biblio/biblio informe MedioAmbiente.html

8. El Espectador (2015). Así quedó la ley de Zidres. https://www.elespectador.com/noticias/politica/asiquedo-la-ley-de-zidres/

9. Guerrero, T. A., Furlong, K., \& Arias, J. (2016). Complicating neoliberalization and decentralization: The non-linear experience of Colombian water supply, 1909-2012. International Journal of Water Resources Development, 32(2), 172-188.

10. Hernández, M.C., Saldarriaga, V., Cháves, D.A., 2010. Evaluación de las transferencias del sector eléctrico a las CAR y a los municipios. Econ. Colomb. 330, 66-80.

11. IDEAM (2014). Estudio Nacional del Agua 2014. Bogotá - Colombia.

12. Kathuria, V. (2006). Controlling water pollution in developing and transition countries-lessons from three successful cases. Journal of Environmental Management, 78(4), 405-426. https://doi.org/10.1016/j. jenvman.2005.05.007

13. Kugler, M., \& Rosenthal, H. (2000). Checks and balances: an assessment of the institutional separation of political powers in Colombia.

14. Ministerio de Medio Ambiente y Desarrollo, 2015. Negocios verdes y desarrollo sostenible [WWW Document]. Plantilla negocios verdes y Desarro. Sosten. URL https://www.minambiente.gov.co/index. $\mathrm{php} /$ component/content/article?id=1434:plantilla-negocios-verdes-y-sostenibles-51\#información-deinterés

15. Ministerio de Medio Ambiente y Desarrollo, 2014. Guía Técnica para la formulación de los POMCAS. Bogotá - Colombia.

16. Ministerio de Medio Ambiente y Desarrollo, 2010. Metodología general para la presentación de estudios ambientales.

17. Monahan, K. 2019. "Ecuador's fuel protests show the risks of removing fossil fuel subsidies too fast," The Conversation, October 31.

18. Moncada, J. Pérez, C. y Valencia, G. (2013). Comunidades organizadas y el servicio público de agua potable en Colombia: una defensa de la tercera opción económica desde la teoría de recursos de uso común. Ecos de Economía, 17(37). pp. 125-159.

19. Ménard, C., \& Shirley, M. M. (Eds.). (2008). Handbook of New Institutional Economics. Springer Berlin Heidelberg. Doi: 10.1007/978-3-540-69305-5

20. OECD, (2014). OECD Environmental Performance Reviews. OECD Environmental Performance Reviews: Colombia 2014. 
21. Ostrom, E., (2005). Understanding Institutional Diversity, Public Choice. Doi:10.1007/s11127-0079157-x

22. Peláez, C., (2015). Entrevista profesor Carlos Peláez.

23. Rodríguez, C., (2012). La paradoja de las instituciones en Colombia: un análisis sociológico, en: Las Instituciones En Colombia. Un Análisis Sociológico. pp. 56-85.

24. Sánchez, A., (2011). Reformas fiscales verdes y la hipótesis del doble dividendo: un ejercicio aplicado a la economía colombiana. Doc. Trab. sobre Econ. Reg. 49.

25. Supersociedades, (2015). Sistema de Información y Reporte Empresarial -SIREM- [WWW Document]. URL http://www.supersociedades.gov.co/asuntos-economicos-y-contables/estudios-y-supervision-porriesgos/SIREM/Paginas/default.aspx

26. Tacconi, L. (2012). Redefining payments for environmental services. Ecological Economics, 73, 29-36. Doi: 10.1016/j.ecolecon.2011.09.028

27. Tobón Orozco D. \& Vasco, C.A. (2019). Mecanismos de política económica ambiental: retos en la prestación del servicio de aseo en grandes ciudades. Universidad de Antioquia. https://books.google.com.co/ books?hl=en\&lr=\&id=q4aWDwAAQBAJ\&oi=fnd\&pg=PA3\&dq=info:x2_kdw_yaTsJ:scholar.google. com\&ots=amcCjGwD63\&sig=hzBW6FvzVl3908r4cvRcVukazVI\&redir_esc $=y \# v=$ onepage \&q\&f=false

28. Tobón Orozco, D., Molina, C., \& Vasco, C.A. (2018), Riesgo de desabastecimiento en la provisión de agua potable en grandes ciudades y políticas económicas ambientales híbridas, Colciencias \& Universidad de Antioquia.

29. Hitzhusen, F. J. (2000). Greening Industry: New Roles for Communities, Markets and Governments. Journal of Environmental Quality, 29(6), 2049-2050. Doi: 10.2134/jeq2000.00472425002900060050x

30. UPME, 2015. Proyectos de Eficiencia Energética [WWW Document]. https://www1.upme.gov.co/ paginas/demanda-y-eficiencia-energetica.aspx

31. Chandler, R., Rougier, J., \& Collins, M. (2010). Climate change. Significance, 7(1), 9-12. https://doi. org/10.1111/j.1740-9713.2010.00403.x

32. Wills, M., Irvine, K., 1996. Application of the National Sanitation Foundation Water Quality Index in Cazenovia Creek, NY, Pilot Watershed Management Project. Middle States Geogr. 95-104.

33. Kugler, M. \& Rosental, M. (2000). Checks and balances: an assessment of the institutional separtion of political powers in Colombia, Working Papers Series. Documentos de Trabajo 002117, Fedesarrollo.

34. Wijen, F., \& van Tulder, R. (2011). Integrating environmental and international strategies in a world of regulatory turbulence. California management review, 53(4), 23-46.

35. Yale University, (2015). Environmental Performance Index [WWW Document]. Yale Cent. Environ. Law Policy. URL http://epi.yale.edu/ (acce 